\title{
GASTROESOPHAGEAL REFLUX DISEASE AND BRONCHIAL ASTHMA: MECHANISMS OF COMORBID FORMATION AND COURSE
}

\author{
Aleksey Oparin ${ }^{1}$ \\ Givi Akhvlediani ${ }^{1}$ \\ Anatoliy Oparin ${ }^{1}$ \\ Sergei Pavlov \\ Central research laboratory ${ }^{2}$ \\ ${ }^{1}$ Department of Therapy, Rheumatology and Clinical Pharmacology \\ ${ }^{2}$ Kharkiv Medical Academy of Postgraduate Education \\ 58 Amosova str., Kharkiv, Ukraine, 61176
}

\begin{abstract}
The aim of the study: To estimate the level of Galectin- 3 with the parallel tracing of the content of pro- and anti-inflammatory cytokines Interleukin-6 (IL-6) and Interleukin-4 (IL-4) for patients with GERD and BA both in case of separate nosologies, and in case of their combined course during the period of exacerbation of the diseases.

Methods. The study was conducted in three groups of patients, homogeneous by gender and age. The first group included 18 patients with GERD. The second group included 19 patients with intermittent or persistent-mild bronchial asthma. The third group included 22 patients suffering from GERD with concomitant BA intermittent or persistent-mild severity. Determination of the level of galectin-3 and interleukins (IL-4 and IL-6) in the blood serum was carried out by enzyme-linked immunosorbent assay.

Results. Analyzing the results of the study, we found that the level of galectin - 3 was increased on average in both groups of patients with isolated GERD (and in patients with BA). In patients of the third group with comorbid pathology, the level of galectin-3 was statistically significantly higher than not only the norm, but also the average of patients with isolated BA and GERD. At the same time, we found the rise in the level of pro-inflammatory (IL-6) and anti-inflammatory (IL-4) cytokines. Moreover, in patients with GERD, the level of IL- 6 was increased with a higher degree of reliability, and the level of IL-4 was increased with a lower degree of reliability. In patients with BA, on the contrary, the level of IL- 4 was determined more often and higher, and the level of IL- 6 was lower.

Conclusions. Analyzing result of the study, a clear correlation and features of changes in the level of galectin-3, IL-4, IL-6 in patients with isolated GERD, BA, as well as with the comorbidity of these diseases, were revealed.

In patients with BA, the level of galectin-3 increases with the same degree of certainty as in the group of patients with GERD. In the cytokine system, on the contrary, the level of anti-inflammatory (IL-4) cytokines increases with a greater degree of certainty than the level of pro-inflammatory (IL-6) cytokines.

In patients with GERD with concomitant BA, the level of galectin-3 increases with a greater degree of certainty. It is observed also a higher rising of pro-inflammatory (IL-6) cytokines and a slightly pronounced increasing of the level of anti-inflammatory (IL-4) cytokines in comparison with the group of patients with isolated GERD.
\end{abstract}

Keywords: GERD, BA, galectin-3, interleukins, comorbidity.

DOI: $10.21303 / 2504-5679.2020 .001199$

\section{Introduction}

The comorbid course of diseases has become the subject of numerous studies of modern medicine $[1,2]$. Particular attention is paid to a deeper learning of the general pathogenetic mechanisms, to the clinical picture, which can significantly change within several concurrent diseases $[3,4]$. In recent years, special attention has been paid to galectin-3 and its role in the development of numerous physiological and pathological processes [5-7]. Galectin-3 is one of the representatives of the 5-lectin family, that influences intercellular interaction, cell growth, regulation of the cell cycle, apoptosis and, in particular, the nature and the course of inflammatory mechanisms, which violation is one of the key factors in the formation of many diseases of the internal organ systems, including the bronchopulmonary and digestive systems [8, 9]. 
This problem, associated with the process (mechanism) of systemic inflammation, is of particular importance for patients suffered from gastroesophageal reflux disease (GERD) and bronchial asthma (BA) [10, 11]. With the increasing prevalence of BA symptoms among patients with GERD the mutual aggravating effect of these diseases, and as a result an increase in the number of severe forms and the development of combined pathologies is observed [12-14].

However, many issues in regard to the depth and nature of the cytokine system disorder and, especially, to the level of galectin-3 in the development of the GERD/BA, and their comorbidity, have been remaining completely unresolved and require further research [15-17].

The aim of the study. To estimate the level of galectin-3 with the parallel tracing of the content of pro- and anti-inflammatory cytokines Interleukin-6 (IL-6) and Interleukin-4 (IL-4) for patients with GERD and BA both in case of separate nosologies, and in case of their combined course during the period of exacerbation of the diseases.

\section{Materials and methods}

Studies were conducted in 2016, 2017 years on the base of Kharkiv state medical hospitals No. 13 and No. 20 in three groups of patients, homogeneous by gender and age. The first group included 18 patients (10 men and 8 women) in age of 18 to 45 years (average age 24.4 \pm 2.3 ) with gastroesophageal reflux disease. 15 patients had a non-erosive form, and three patients had an erosive form of GERD. The second group included 19 patients with intermittent and persistent-mild bronchial asthma. Among them were 12 men and 7 women, age range was 19 to 38 years (average age 25.1 \pm 2.96 ). The third group included 22 patients ( 14 men and 8 women) in age of 18 to 36 years (average age 25.2 \pm 2.10 ), that were suffering from erosive GERD (5 patients), and a non-erosive GERD (17 patients) with concomitant intermittent or persistent-mild bronchial asthma.

The diagnosis of GERD was made according to ICD-10, the Montreal Consensus (2006), questionnaire data, that was developed at the "Therapy National Institute named after L. T. Malaya of the National Academy of Medical Sciences of Ukraine" (application 2625 from July 4, 2008), the results of esophagogastroduodenoscopy, fluoroscopy of the esophagus and stomach, as well as the results of $\mathrm{pH}$ measurement.

The diagnosis of asthma was verified in accordance with the recommendations of WHO (GINA), ICD-10 by the order of the Ministry of Health of Ukraine No. 868 (08.10. 2013), taking into account the results of spirography and radiography of the chest organs. Exclusion criteria were other organic diseases in patients (including the digestive and respiratory systems), severe BA, and refusal of patients to participate in the study.

Determining the level of galectin-3 in the blood was carried out by an enzyme-linked immunosorbent assay using the Human galectin-3 platinum ELISA reagent kit, manufactured by Bioscience (Austria). The level of interleukins in the blood serum was determined by the method of immuno-enzyme analysis using test systems "Vector Best". Average values of 20 healthy individuals of the control group of the same age and gender were taken as normal.

Statistical processing was carried out by the method of variation statistics using the standard software Statistica 6.0 with calculation of arithmetic mean values: M, m. The difference was evaluated by the by Student's t-test. The difference was considered as significant at $p<0.05$. To build-up the relationship between the indicators, a correlation analysis was used with the calculation of the correlation coefficient (r) and estimating of its reliability.

\section{Results}

In the course of the study, we found that in patients with GERD and BA and in patients with comorbidity of these diseases, are developing the typical for each group of the patients' changes in blood levels of galectin-3 and cytokines - IL-4 and IL-6. In particular, the level of galectin-3 was increased on average both in patients with isolated GERD (up to $11.15 \pm 1.05 \mathrm{ng} / \mathrm{ml}$ ) at normal rates $(5.61 \pm 0.79 \mathrm{ng} / \mathrm{ml})$ and in patients with BA - (up to $11.90 \pm 1.27 \mathrm{ng} / \mathrm{ml}$ ). When compared to normal, the difference in both the first and second groups of patients was equally statistically significant $(\mathrm{p}<0.001)$. In patients of the third group with comorbid pathology, the level of galectin-3 was much higher and on average its level $(16.41 \pm 1.76 \mathrm{ng} / \mathrm{ml})$ was statistically significantly higher not only 
than normal values $(\mathrm{p}<0.001)$, but also average values of patients with isolated $B A(p<0.05)$ and GERD $(\mathrm{p}<0.05)$.

At the same time, in these patients we found an increase in the level of pro-inflammatory (IL-6) and anti-inflammatory (IL-4) cytokines. Moreover, in patients with GERD with a higher degree of certainty, the level of IL- 6 was increased (up to $9.70 \pm 0.65 \mathrm{pg} / \mathrm{ml}$ ) at normal rates $(5.33 \pm 0.58 \mathrm{pg} / \mathrm{ml})$ and the level of IL-4 increased with a lower degree of certainty - up to $2.70 \pm 0.11$ with a normal of $1.71 \pm 0.21 \mathrm{pg} / \mathrm{ml}$. (Table 1).

\section{Table 1}

The level of galectin-3 and cytokines in the blood of patients with GERD, AD and their comorbidity and healthy individuals in the control group.

\begin{tabular}{|c|c|c|c|c|c|}
\hline \multirow[b]{2}{*}{ Indices } & \multicolumn{3}{|c|}{ Patients } & \multirow{2}{*}{$\begin{array}{l}\text { Control group } \\
\mathbf{n}=\mathbf{2 0}\end{array}$} & \multirow[b]{2}{*}{$\mathbf{p}$} \\
\hline & $\begin{array}{c}\text { GERD } \\
\mathrm{n}=18\end{array}$ & $\begin{array}{c}\text { BA } \\
n=19\end{array}$ & $\begin{array}{l}\text { GERD and concomitant BA } \\
n=22\end{array}$ & & \\
\hline Galectin $-3 \mathrm{ng} / \mathrm{ml}$ & $11.15 \pm 1.05$ & $11.9 \pm 1.27$ & $16.41 \pm 1.76$ & $5.61 \pm 0.79$ & $\mathrm{p}<0.001$ \\
\hline IL-4 pg/ml & $2.70 \pm 0.11$ & $3.82 \pm 0.35$ & $2.75 \pm 0.22$ & $1.71 \pm 0.21$ & $\mathrm{p}<0.001$ \\
\hline IL-6 pg/ml & $9.70 \pm 0.65$ & $7.21 \pm 0.56$ & $11.90 \pm 0.86$ & $5.33 \pm 0.58$ & $\mathrm{p}<0.001$ \\
\hline Ratio index IL-6/IL-4 & $\begin{array}{c}4.15 \\
3.59 \pm 0.34\end{array}$ & $\begin{array}{c}1.88 \\
1.88 \pm 0.19\end{array}$ & $\begin{array}{c}4.33 \\
4.33 \pm 0.29\end{array}$ & $\begin{array}{c}3.11 \\
3.11 \pm 0.18\end{array}$ & $\mathrm{p}<0.001$ \\
\hline
\end{tabular}

Note: $p$-confidence level

In patients with BA, on the contrary, the level of IL-6 (up to $7.21 \pm 0.56 \mathrm{pg} / \mathrm{ml}$ ) was lower and the level of IL-4 (up to $3.82 \pm 0.35 \mathrm{pg} / \mathrm{ml}$ ) was higher. In BA patients, the average level of IL-4 in relation to the normal value $(\mathrm{p}<0.001)$ and in relation to the average index of the group of GERD-patients $(\mathrm{p}<0.05)$ was statistically significantly higher. The average level of IL-6 in relation to the normal value was statistically significantly higher too $(\mathrm{p}<0.05)$, but in relation to the average index of the group of GERD-patients - statistically significantly lower $(p<0.001)$ (Table 1).

In patients of the third group with comorbid pathology, the level of IL-6 increased up to $11.90 \pm 0.86 \mathrm{pg} / \mathrm{ml}$, that was statistically significantly higher $(\mathrm{p}<0.001)$ in relation to the normal value and to the average indexes of patients with isolated GERD and BA. The average level of IL-4 $(2.75 \pm 0.22 \mathrm{pg} / \mathrm{ml})$ was, on the contrary, statistically significantly lower than in patients with BA $(3.82 \pm 0.35 \mathrm{pg} / \mathrm{ml})$, but remained statistically significantly higher $(\mathrm{p}<0.01)$, than in the group of healthy individuals, as well as patients with GERD without a combined pathology $(\mathrm{p}<0.05)$; Table 1 .

\section{Discussion}

These facts are clearly showing that in patients with an exacerbation of the disease, not only the level of cytokines increases, but also an imbalance arises, i. e. the ratio of pro- and anti-inflammatory cytokines IL-6/IL-4 changes. It decreases to 1.88 while a norm of 3.11 in BA patients and increases to 4.15 and 4.33 in patients with GERD and comorbidity respectively $(\mathrm{p}<0.001)$; Table 1. According to recent studies, it is believed that chronic aspiration associated with gastroesophageal reflux disease (GERD) plays a significant role in the development of asthma [11, 16, 18-20]. Experimental observations of the relationship between aspiration and asthma obtained during epidemiological studies show that between 50 and $90 \%$ of people with asthma suffering from some symptoms of GERD. It was proved [19] that as a result of the reflux-induced airway hypersensitivity, a tendency is observed to decrease the production of $\operatorname{IgG}$ anti-ovalbumin, IgE anti-ovalbumin and total IgE. In addition, aspiration induces a significant increase of the anti-ovalbumin ratio $\mathrm{IgG1} / \mathrm{IgG} 2 \mathrm{a}$, that is consistent with a shift towards a predominantly Th2 response.

According to $[18,19]$, the urgency of this problem is also due to the fact that the etiology and pathogenesis of GERD and BA are different, but they have a common component - inflammation with impaired immune responses in the form of an imbalance between cellular (ThI) and humoral (Th2) one. Response cells can acquire either a pro-inflammatory (M1) or alternatively anti- 
inflammatory (M2) phenotype [21, 22], depending on many factors and first of all on the prevalence of cytokine levels $[11,18]$.

In unison with other researcher [18], who were monitoring the level of other pro-inflammatory (IL-1 $\beta$, IL-8, IL-12) and anti-inflammatory (IL-5, IL-10) cytokines and their correlation, we have established that the level of alveolar macrophages in BA patients shifts toward the predominance of anti-inflammatory cytokines, and in GERD-patients - mainly towards pro-inflammatory cytokines. In patients with a combined pathology, it is seen a higher rise of M1 phenotype markers $(\mathrm{p}<0.05)$ and, to a lesser extent - of M2 phenotype $(\mathrm{p}<0.05)$.

But we have first found up the role and place of galectin-3 in the mechanisms of the comorbid course of GERD and BA. Our data clearly indicates an increase in the level of galectin-3 and an imbalance in simultaneously characteristic for each pathology system of pro- and anti-inflammatory cytokines (IL-4, IL-6) for each of these diseases during exacerbation. The identified changes of the studied parameters and their close correlation $(\mathrm{p}<0.05, \mathrm{r}=0.47)$ are additionally confirming that the systemic inflammation occupies a central place in the mechanisms of formation of the pathologies under consideration - whether GERD, BA or their combination and at the same time, indicates the need for a differentiated approach to the prevention and medication of such patients.

Study limitations. The study was not conducted in case of identified concomitant pathology of another organs and in case of patients refuse to participate in the study.

Prospects for further research. Determination of the level of galectin-3 and the content of pro- and anti-inflammatory cytokines (IL-4, IL-6) in patients with GERD and BA, as well as their comorbidity, indicate the advisability of studying them with the aim of diagnosing the disease at an earlier stages of their development and timely appointment of an adequate medication method of therapy.

\section{Conclusions}

In patients with GERD, the activity of systemic inflammation increases, as evidenced by a statistically significant increasing of the content of galectin-3 and an imbalance in the cytokine system with the highest rise of pro-inflammatory (IL-6) cytokines compared to the level of anti-inflammatory (IL-4) cytokines.

In patients with BA, the level of galectin-3 increases with the same degree of certainty as in the group of patients with GERD. In the cytokine system, on the contrary, the level of anti-inflammatory (IL-4) cytokines increases with a greater degree of certainty than the level of pro-inflammatory (IL-6) cytokines.

In patients with GERD with concomitant BA, the level of galectin-3 increases with a greater degree of certainty. It is observed also a higher rising of pro-inflammatory (IL-6) cytokines and a slightly pronounced increasing of the level of anti-inflammatory (IL-4) cytokines in comparison with the group of patients with isolated GERD.

\section{Conflict of interests}

The authors declare that they have no conflicts of interest.

\section{References}

[1] Oparin, A. G., Oparin, A. A., Titkova, A. V. (2013). Rol soputstviushchei gastroezofagealnoi refliuksnoi bolezni v mekhanizme formirovaniia vospalitelnogo gomeostaza u bolnykh khronicheskoi obstruktivnoi bolezniu legkikh. Nauchnaia vzaimosviaz. Farmatsiia, 1 (154), 83-85.

[2] Paleev, N. R., Isakov, V. A,, Ivanova, O. V. (2005). Bronkhialaia astma i gastroezofagealnaia refliuksnaia bolezn: sluchaina li vzaimosviaz? Klinicheskaia meditsina, 1, 9-14.

[3] Panfilova, E. F. (2008). Novye biomarkery serdechnoi nedostatochnosti. Aktualnye voprosy. Farmateka, $12,14$.

[4] Fadeenko, G. D., Gridnev, A. E. (2014). Gastroezofagealnaia refliuksnaia bolezn: pishchevodnye i vnepishchevodnye proiavleniia i komorbidnost. Kyiv, 367.

[5] Fucumori, T., Takenoka, V., Yoshii, T., Kim, H. R., Hogan, V., Inohara, H. et. al. (2003). CD29 and CD7 mediate galectin-3 induced type II T-cell apoptosis. Cancer Research, 63, 831. 
[6] Christenson, R. H., Duh, S.-H., Wu, A. H. B., Smith, A., Abel, G., deFilippi, C. R. et. al. (2010). Multi-center determination of galectin-3 assay performance characteristics: Clinical Biochemistry, 43 (7-8), 683-690. doi: http://doi.org/10.1016/j.clinbiochem.2010.02.001

[7] Gehlken, C., Suthahar, N., Meijers, W. C., de Boer, R. A. (2018). Galectin-3 in Heart Failure. Heart Failure Clinics, 14 (1), 75-92. doi: http://doi.org/10.1016/j.hfc.2017.08.009

[8] Arutiunov, A. G., Burkov, S. G., Shcherba, E. P. (2004). Mekhanizmy vzaimosviazi gastroezofagealnoi refliuksnoi bolezni i bronkhialnoi astmy i taktika vedeniia bolnykh. Klinicheskie perspektivy gastroenterologii i gepatologii, 2 (204), 5-9.

[9] Berezniakov, V. I., Korzh, A. N. (2015). Soderzhanie prokaltsitonina galektina - 3 v krovi bolnykh s vnebolnichnoi pnevmoniei i soputstvuiushchei serdechnoi nedostatochnostiu i bez nee. Mezhdunarodnii meditsinskii zhurnal, 4, $13-17$.

[10] Korabelnikov, D. I., Chuchalin, A. G. (2002). Bronkhialnaia astma i soputstvuiushchiei zabolevaniia organov pishchevareniia. Pulmonologiia, 5, 87-92.

[11] Liamina, S. V., Kruglov, S. V., Vedenikin, T. Iu. (2011). Novaia strategiia upravleniia immunnym otvetom pri zabolevaniiakh legkikh - rol surfaktantnogo belka D kak bivalentnogo faktora reprogrammirovaniia makrofagov. Fundamentalnye issledovaniia, 1, 90-98.

[12] Doehner, W. (2012). Diagnostic biomarkers in cardiovascular disease: the proteomics approach. European Heart Journal, 33 (18), 2249-2251. doi: http://doi.org/10.1093/eurheartj/ehs187

[13] Lok, D. J. A., Van Der Meer, P., de la Porte, P. W. B.-A., Lipsic, E., Van Wijngaarden, J., Hillege, H. L., van Veldhuisen, D. J. (2010). Prognostic value of galectin-3, a novel marker of fibrosis, in patients with chronic heart failure: data from the DEAL-HF study. Clinical Research in Cardiology, 99 (5), 323-328. doi: http://doi.org/10.1007/s00392-010-0125-y

[14] Mueller, T., Leitner, I., Egger, M., Haltmayer, M., Dieplinger, B. (2015). Association of the biomarkers soluble ST2, galectin-3 and growth-differentiation factor-15 with heart failure and other non-cardiac diseases. Clinica Chimica Acta, 445, $155-160$. doi: http://doi.org/10.1016/j.cca.2015.03.033

[15] Lakomkin, A. A., Skvortsova, T. V., Gariunova, T. V. (2012). Galektin-3 - novii marker diagnostiki i prognoza serdechnoi nedostatochnosti. Kardiologiia, 3, 45-52.

[16] Maev, I. V., Liamina, S. V., Kalish, S. V., Malysheva, E. V. (2014). Funktsionalnaia aktivnost alveoliarnykh makrofagov u bolnykh bronkhialnoi astmoi i gastroezofagealnoi refliuksnoi bolezniu. Klinicheskaia meditsina, 6, 41-48.

[17] Woodruff, P. G., Modrek, B., Choy, D. F., Jia, G., Abbas, A. R., Ellwanger, A. et. al. (2009). T-helper Type 2-driven Inflammation Defines Major Subphenotypes of Asthma. American Journal of Respiratory and Critical Care Medicine, 180 (5), 388-395. doi: http://doi.org/10.1164/rccm.200903-0392oc

[18] Maev, I. V., Liamina, S. V., Malysheva, E. V., IUrenev, G. L. (2015). Immunnii otvet i fenotip alveoliarnykh makrofagov pri bronkhialnoi astme, gastroezofagealnoi refliuksnoi bolezni i ikh sochetanii. Terapevticheskii arkhiv, 3, 34-41.

[19] Barbas, A. S., Downing, T. E., Balsara, K. R., Tan, H. E., Rubinstein, G. J., Holzknecht, Z. E. et. al. (2008). Chronic aspiration shifts the immune response from Th1 to Th2 in a murine model of asthma. European Journal of Clinical Investigation, 38 (8), 596-602. doi: http://doi.org/10.1111/j.1365-2362.2008.01976.x

[20] Gow, A. J., Guo, C. (2011). Surfactant Protein-D Regulates Alveolar Macrophage Phenotype. American Journal of Respiratory and Critical Care Medicine, 183, 1085. doi: http://doi.org/10.1164/ajrccm-conference.2011.183.1_meetingabstracts.a1085

[21] Martinez, F. O., Gordon, S., Locati, M., Mantovani, A. (2006). Transcriptional Profiling of the Human Monocyte-to-Macrophage Differentiation and Polarization: New Molecules and Patterns of Gene Expression. The Journal of Immunology, 177 (10), 7303-7311. doi: http://doi.org/10.4049/jimmunol.177.10.7303

[22] Woodruff, P. G., Modrek, B., Choy, D. F., Jia, G., Abbas, A. R., Ellwanger, A. et. al. (2009). T-helper Type 2-driven Inflammation Defines Major Subphenotypes of Asthma. American Journal of Respiratory and Critical Care Medicine, 180 (5), 388-395. doi: http://doi.org/10.1164/rccm.200903-0392oc 